\title{
Batal Demi Hukum: Poligami Tanpa Persetujuan Isteri: Studi Kasus POLDA Provinsi Maluku Utara
}

\author{
Muhammad Zaber Wahid \\ Institut Agama Islam Negeri (IAIN) Ternate \\ Baharuddin Hi. M.A Hi. Abdullah \\ Institut Agama Islam Negeri (IAIN) Ternate
}

\begin{abstract}
Abstrak
Hukum Perkawinan di Indonesia menganut asas Monogami. Artinya, seorang Suami hanya dapat memiliki seorang isteri. Namun dalam Undang-Undang yang berlaku, tindakan Poligami dimungkinkan dengan beberapa syarat diantaranya Izin isteri dan disahkan oleh pengadilan. Pada prakteknya, banyak pelaksanaan poligami yang dilakukan tanpa sepengetahuan Isteri bahkan dilakukan secara "sirri" atau Nikah di bawah tangan. Penelitian ini bertujuan menganalisis praktek poligami tanpa persetujuan salah satu pihak dalam perspektif hukum perdata dan hukum islam di kota Ternate, bagaimana penyelesaian hukum terhadap kasus pernikahan tanpa persetujuan salah satu pihak pada polda Maluku Utara dan pengadilan agama kota Ternate, tujuan penelitian untuk menganalisis pernikahan (Poligami) tanpa persetujuan salah satu pihak dalam perspektif Hukum Perdata dan Hukum Islam. Penelitian ini menggunakan jenis penelitian kulitatif dengan model deskriptif analitis yang kemudian digabungkan dengan kajian Normatif. Penelitian ini menemukan bahwa perkawinan (poligami) yang dilakukan tanpa sepengetahuan isteri pertama dikatakan batal demi hukum sebab tidak memenuhi unsur-unsur yang ditetapkan undang-undang dan pengadilan.
\end{abstract}

Kata Kunci : Poligami, Tanpa Persetujuan Isteri, Perspektif Hukum Islam, Hukum

Perdata

\section{Abstract}

Marriage Law in Indonesia adheres to the principle of Monogamy. That is, a husband can only have a wife. But in the applicable law, polygamy is possible on several conditions including a wife's license and authorized by the court. In practice, many polygamy practices carried out without the wife's knowledge are even done "sirri" or nikah under the hands. This research aims to analyze the practice of polygamy without the consent of one party in the perspective of civil law and Islamic law in the city of Ternate, how the legal settlement of marriage cases without the consent of one party in the North Maluku police and the religious court of Ternate city, the purpose of the study to analyze marriage (Polygamy) without the consent of either party in the perspective of Civil Law and Islamic Law. This research uses a type of skinative research with an analytical descriptive model which is then combined with normative studies. The study found that marriages (polygamy) performed without the first 
wife's knowledge were said to be null and void because they did not meet the elements set by law and courts.

Keywords: Polygamy, Without Consent, Islamic Legal Perspective, Civil Law

\section{A. Pendahuluan}

Keberadaan Undang-undang Nomor 1 Tahun 1974 dan Intruksi Presiden Nomor 1 Tahun 1991 merupakan payung hukum bagi umat Islam khususnya tentang pengaturan perkawinan. Sebuah perkawinan yang dilaksanakan antara seorang lakilaki dan perempuan tanpa dihadiri oleh pejabat Kantor urusan agama hal ini biasanya terjadi dikalangan anggota masyarakat yang ingin berpoligami atau ingin beristri lebih dari satu secara diam-diam agar tidak diketahui oleh pihak istri atau suami. Pernikahan ini bertentangan dengan Undang-undang Nomor 1 Tahun 1974 yang mengharuskan seorang suami apabila beristri lebih dari satu, harus mendapat persetujuan dari pasangannya dan mendapat ijin dari Pengadilan Agama.

Dalam kehidupan bermasyarakat sering terjadi perkawinan tanpa melalui persetujuan istri, walaupun dalam regulasi sangat menghendaki demikian. Sebagaimana diatur dalam Pasal 4 ayat (2) Undang-undang Nomor 1 Tahun 1974, akan tetapi masih ada pihak istri yang keberatan untuk mengijinkan suaminya untuk menikah lagi.

Ada beberapa alasan bagi seorang suami melakukan pernikahan tanpa meminta persetujuan kepada pasangannya ketidakharmonisan dalam hubungan rumah tangga, sifat bosan kepada istrinya, kecantikan istrinya sudah berkurang, pelayanan kebutuhan bathinia sudah berkurang karena istri telah mencapai masa monoupose, istri sering mengeluarkan kata-kata yang berlebihan yang menimbulkan ketersingungan seorang suami atau istri telah mengabaikan tata busana disertai dengan tidak memakai make up dan lain sebagainya. Hal-hal seperti inilah yang dapat mempengaruhi seorang suami melakukan pernikahan yang kedua kalinya, dari alasan dari penyebab yang paling dominan adalah terkait hubungan biologis.

Kasus pernikahan yang dilakukan tanpa persetujuan salah satu pihak selama lima tahun terakhir di Polisi Daerah (POLDA) Provinsi Maluku Utara sejak tahun 2013 hingga tahun 2017 sebanyak 35 kasus dan telah dilimpahkan ke Pengadilan 
Agama dan Pengadilan Negeri masing-masing 20 kasus di Pengadilan Agama dan 15 kasus di Pengadilan Negeri. Adapun kasus yang telah diselesaikan baik di Pengadilan agama maupun di Pengadilan Negeri sebanyak 10 kasus. ${ }^{1}$

Dari uraian diatas saya tertarik untuk melakukan penelitian sah tidaknya suatu pernikahan tanpa melalui persetujuan salah satu pihak, dan bagaimana pernikahan dilakukan tanpa mendapatkan akta nikah, serta kedudukan hukum perkawinan dilihat dari Hukum Perdata dan Hukum Islam. Adapun judul penelitian adalah “Praktek Poligami Tanpa Persetujuan Salah Satu Pihak Dalam Perspektif Hukum Islam Dan Hukum Perdata ( Studi Kasus POLDA Provinsi Maluku Utara)".

Ada beberapa variable yang dijadikan permasalahan dalam penelitian ini diantaranya, Bagaimana Praktek Poligami Tanpa Persetujuan Salah Satu Pihak Dalam Perspektif Hukum Perdata Dan Hukum Islam di Kota Ternate? Kemudian, bagaimana Penyelesaian Hukum Terhadap Kasus Praktek Poligami Tanpa Persetujuan salah satu pihak pada Polda Maluku Utara dan Pengadilan Agama Kota Ternate?. Adapun tempat yang akan peneliti mengambil sumber data dilapangan yaitu Polda Maluku Utara dan Pengadilan Kota Ternate, sedangkan waktu penelitian adalah 2 Januari sampai 20 Juli 2020.

Setelah data diperoleh penulis akan menganalisis dengan pendekatan kualitatif deskrifti. Melalui observasi, wawancara sampai pada pengelolaan data. Dan dikelola secara sistematis agar menghasilkan hasil penelitian yang berkopotensi. Akan dianalisis secara deskriptif kualitatif. Analisis deskriptif kualitatif yaitu metode analisis data yang mengelompokkan dan menyelesaikan data yang diperoleh dari teor-teori, asas-asas dan kaidah-kaidah hukum yang diperoleh dari studi pustaka dan dihubungkan oleh data yang diperoleh dari lapangan sehingga diperoleh jawaban dari permasalahan yang dirumuskan tersebut.

B. Tinjauan Umum Pernikahan di Indonesia

1. Sejarah Perkembangan Hukum "Pernikahan" di Indonesia

${ }^{1}$ Muhammad Zaber Wahid, Data Kasus Pernikahan (Poligami) Tanpa Persetujuan Salah Satu Pihak Di Kepolisian Daerah Maluku Utara 2013-2017 (Ternate, 2017). 
Agama Islam masuk ke Indonesia pada abad ke VII Masehi yang di bawah oleh para pedagang-pedagang Arab. Perkembangan hukum Islam di Indonesia menjelang abad XVII, XVIII, dan XIX, baik dalam tatanan intelektual dalam bentuk kitab-kitab dan pemikiran dalam praktek-praktek sangat mengalami kemajuan. Praktek dalam bentuk muamalah (perkawinan, perceraian dan pewarisan), peradilan, dan bentuk ibadah. Hukum Islam di terapkan di kerajaankerajaan Islam di seluruh nusantara. Jauh sebelumnya bangsa Belanda masuk ke Indonesia, hukum Islam menjadi hukukm positif di Indonesia. ${ }^{2}$

Perkembangan hukum Islam di Indonesia pada masa penjajahan bangsa Belanda dapat di bedakan dalam dua bentuk. Pertama, adanya toleransi pihak Belanda melalui VOC (Verrenigde Oots- Indische Compagnie)yang memberikan ruang agak luas bagi perkembangan hukum Islam, kedua, adanya upaya intervensi Belanda terhadap hukum Islam dengan menghadapkan pada hukum Adat. Hukum Islam dapat berkembang di Indonesia walaupun adanya campur tangan dari VOC. Bahkan dapat dikatakan bahwa VOC dapat membantu penyusunan peraturan hukum perkawinan dan hukum kewarisan berlaku dikalangan umat Islam. ${ }^{3}$

Setelah kekuasaan VOC berakhir dan digantikan pihak Belanda, maka sikap Belanda berubah terhadap hukum Islam. Kendati perubahan ini terjadi secara perlahan-lahan. Perubahan-perubahan dapat terlihat dari tiga aspek yaitu :

a. Menguasai Indonesia sebagai wilayah yang mempunyai sumber daya alam yang cukup kaya.

b. Menghilangkan pengaruh Islam dari sebagian besar orang Indonesia dengan proyek kristenisasi.

c. Keinginan belanda ingin menerapkan apa yang disebut dengan politik hokum yang sadar terhadap Indonesia.Belanda ingin mengubah hukum Indonesia dengan hukum Belanda. ${ }^{4}$

2 Abdul Rahman Ghozali, Fiqih Munakahat (Jakarta: Kencana Prenada Media Group, 2012).

${ }^{3} \mathrm{H}$. Amiur Nuruddin and Azhari Taringan, Hukum Perdata Islam Di Indonesia, 3rd ed. (Jakarta: Kencana, 2006).

${ }^{4}$ Ibid. 
Pada prakteknya pihak Belanda memberikan perhatian yang khusus hanya pada hukum keluarga Islam. ${ }^{5}$ Pemerintah Belanda memberikan perhatian yang serius terhadap perjalanan hukum Islam. Sebagai contoh melalui stabl. Nomor 22 Pasal 13 di perintahkan kepada Bupati untuk memperhatikan soal-soal agama dapat melakukan tugas sesuai dengan adat istiadat orang jawa seperti soal perkawinan, pembagian pusaka dan sejenis.Perkawinan bagi hukum adat berlaku bagi golongan pribumi, yang tidak memeluk agama Islam maupun kristen. Peraturan tentang perkawinan inipun merupakan konsekuensi politik hukum Belanda sampai abad XIX istilah hukum adat ini tidak dikenal. Pada akhir tersebut barulah istilah hukum adat dikenal. Istilah oleh Snouck Hugronje yang mendalami kesusilaan dan berbagai penduduk di Indonesia. ${ }^{6}$

\section{Pengertian Pernikahan}

Pernikahan merupakan salah satu jalan atau suratan hidup yang dialami oleh hampir semua manusia di muka bumi ini walaupun ada beberapa diantaranya yang tidak terikat dengan perkawinan sampai ajal menjemput. Semua agama resmi di Indonesia memandang perkawinan sebagai sesuatu yang sacral. Harus dihormati dan harus dijaga kelanggenangnya. Oleh karena itu setiap orang tua merasa tugasnya sebagai orang tua telah selesai bila anaknya telah memasuki jenjang perkawinan. ${ }^{7}$

Pernikahan atau perkawinan ialah akad yang menghalalkan pergaulan dan membatasi hak dan kewajiban antara seorang laki-laki dan seorang perempuan yang bukan mahram. ${ }^{8}$ Dalam kitab-kitab fikih, pembahasan pernikahan dimasukkan dalam suatu bab yang disebut dengan mun̄̄kahat. Menurut bahasa, kata "nikah" berarti adh-dhammu wattadōkhul (bertindih dan memasukkan). Dalam kitab lain, kata nikah diartikan dengan adh-dhammu wa al-jam'u (bertindih dan berkumpul). Oleh karena itu, menurut kebiasaan Arab, pergesekan rumpun

\footnotetext{
${ }^{5}$ Muhdan Ulfa, Tinjauan Yurudis Terhadap Perkawinan Tanpa Akad Nikah Menurut Undang-Undang Nomor 1 Tahun 1974 Dan Kaitannya Dengan Hukum Islam (Jakarta: Persada Media, 2008).

${ }^{6}$ Wila Chandrawila Supriadi, Hukum Perkawinan Di Indonesia Dan Belanda (Bandung: Mandar Maju, 2002).

${ }^{7}$ Syarifuddin Amir, Hukum Perkawinan Di Indonesia (Jakarta: Prenada Media Group, 2009).

${ }^{8}$ Beni Ahmad Saebani, Fikih Munakahat 1 (Bandung: Pustaka Setia, 2009).
} 
pohon seperti bambu akibat tiupan angin diistilahkan dengan tan̄̄kahatil asyjō $r$ (rumpun pohon itu sedang kawin), karena tiupan angin itu menyebabkan terjadinya pergesakkan dan masuknya rumpun yang satu keruang yang lain. ${ }^{9}$

Menurut istilah ilmu fikih, nikah berarti suatu akad (perjanjian) yang mengandung kebolehan melakukan hubungan seksual dengan memakai lafazh "nikōh" atau "tazwīj". Nikah atau jimō', sesuai dengan makna linguistiknya, berasal dari kata "al-wath", yaitu bersetubuh atau bersenggama. Nikah adalah akad yang mengandung pembolehan untuk berhubungan seks dengan lafazh "an-nik̄ah" atau "at-tazwij", artinya bersetubuh, dengan pengertian menikahi perempuan makna hakikatnya menggauli istri dan kata "munākahat" diartikan saling menggauli. ${ }^{10}$

3. Prinsip dan Syarat Perkawinan

Wahbah al-Zuhaili merumuskan beberapa prinsip dalam perkawinan menurut ajaran Islam, diantaranya: ${ }^{11}$

a. Harus ada persetujuan secara suka rela dari pihak-pihak yang mengadakan perkawinan. Caranya adalah diadakan peminangan terlebih dahulu untuk mengetahui apakah kedua belah pihak setuju untuk melaksanakan perkawinan atau tidak.

b. Tidak semua wanita dapat dikawini oleh seorang pria, sebab ada ketentuan larangan-larangan perkawinan antara pria dan wanita yang harus di indahkan.

c. Perkawinan harus dilaksanakan dengan memenuhi persyaratanpersyaratan tertentu, baik yang menyangkut kedua belah pihak maupun yang berhubungan dengan pelaksanaan perkawinan itu sendiri.

d. Perkawinan pada dasarnya adalah untuk membentuk satu keluarga atau rumah tangga tentram, damai, dan kekal untuk selama-lamanya.

e. Hak dan kewajiban suami istri adalah seimbang dalam rumah tangga, dimana tanggung jawab pimpinan keluarga ada pada suami.

\footnotetext{
9 Ibid.

10 Ibid.

11 Wahbah Al-Zuhaili, Figh Islam Wa Adillatuhu (Bogor: Gema Insani Press, 2007).
} 
Hak dan kewajiban dalam hukum keluarga dapat dibedakan kedalam tiga macam yaitu :

a. Hak dan kewajiban antara suami istri.

b. Hak dan kewajiban antara orang tua dan anaknya.

c. Hak dan kewajiban antara anak dengan orang tuanya manakala orang tuanya telah mengalami proses penuaan.

Hak kewajiban antara suami istri adalah hak dan kewajiban timbul karena adanya perkawinan antara mereka. Hak dan kewajiban suami istri diatur dalam Pasal 32 sampai dengan Pasal 36 Undang-Undang Nomor 1 Tahun 1974, hak dan kewajiban suami istri sebagai berikut : 12

a. Menegakkan rumah tangga;

b. Keseimbangan dalam rumah tangga dan dalam pergaulan masyarakat;

c. Suami istri berhak untuk melakukan perbuatan hukum;

d. Suami istri wajib mempunyai tempat kediaman yang tetap;

e. Suami istri wajib saling mencintai, hormat menghormati, setia dan memberi bantuan lahir bathin yang satu kepada yang lain;

f. Suami wajib melindungi istrinya dan memberikan sesuatu keperluan rumah tangga sesuai dengan kemampuannya;

g. Istri wajib mengatur keperluan rumah tangga sebaik-baiknya.

Pada dasarnya tidak semua pasangan laki-laki dan wanita dapat melangsungkan perkawinan. Namun yang dapat melangsungkan perkawinan adalah mereka - mereka yang telah memenuhi syarat-syarat yang telah ditentuka di dalam peraturan perundang-undangan. Syarat-syarat melangsungkan perkawinan diatur dalam Pasal 6 sampai dengan Pasal 7 Undang-Undang Nomor 1 Tahun 1974. Di dalam ketentuan itu ditentukan dua syarat yaitu syarat intern dan syarat ekstern. Syarat intern adalah syarat yang menyangkut pihak yang akan melangsungkan perkawinan. Syarat-syarat intern itu :

a. Persetujuan kedua belah pihak

b. Izin dai kedua orang tua apabila belum mencapai umur 21 tahun

12 Republik Indonesia, Undang-Undang Nomor 1 Tahun 1974 Tentang Perkawinan. 
c. Pria berumur 19 tahun wanita berumur 16 tahun, pengecualian yaitu ada dispensasi dari Pengadilan atau Camat atau Bupati

d. Kedua belah pihak dalam keadaan tidak mabuk

e. Wanita yang kawin untuk kedua kalinya harus lewat masa tunggu (iddah). Bagi wanita yang putus perkawinannya karena perceraian masa iddahnya 90 hari dan karena kematian 130 hari.

Syarat ekstern, yaitu syarat yang berkaitan dengan formalisasi dalam pelaksanaan perkawinan. Syarat itu meliputi :

a. Harus mengajukan laporan ke Pegawai Pencatat Nikah, Talak dan Rujuk

b. Pengumuman, yang ditandatangani oleh Pegawai Pencatat yang memuat:

1) nama, umur, agama,/kepercayaan, pekerjaan, tempat kediaman dari calon mempelai dan dari orang tua calon. Disamping itu disebutkan juga nama istri atau suami yang terdahulu.

2) hari, tanggal, jam, dan tempat perkawinan dilangsungkan.

Dalam KUH Perdata, syarat untuk melangsungkan perkawinan dibagi dua macam adalah : (1) syarat materiil dan (2) syarat formal. Syarat materiil yaitu syarat yang berkaitan dengan inti atau pokok dalam melangsungkan perkawinan, syarat itu dibagi dua macam, yaitu :13

a. Syarat materiil mutlak, merupakan syarat yang berkaitan dengan pribadi seseorang yang harus di indahkan untuk melangsungkan perkawinan pada umumnya, syarat ini meliputi :

1) monogami, bahwa seorang pria hanya boleh mempunyai seorang istri, seorang wanita hanya boleh mempunyai seroang suami ( Pasal 27 BW)

2) persetujuan antara suami istri ( Pasal 28 KUH Perdata)

3) terpenuhinya batas umur minimal. Bagi laki-laki minimal 18 tahun dan wanita 15 tahun (Pasal 29 KUH Perdata)

4) seorang wanita yang pernah kawin dan hendak kawin lagi harus mengindahkan waktu 300 hari setelah perkawinan terdahulu di bubarkan (Pasal 34 KUH Perdata)

${ }^{13}$ Salim HS., Pengantar Hukum Perdata Tertulis (BW) (Yogyakarta: Sinar Grafika, n.d.). 
5) harus ada izin sementara dari orang tuanya atau walinya bagi anakanak yang belum dewasa dan belum pernah kawin (Pasal 35 sampai dengan Pasal 49 KUH Perdata).

b. Syarat materiil relative, ketentuan yang merupakan larangan bagi seorang untuk kawin dengan orang tertentu. Larangan itu ada dua macam, yaitu :

1) larangan kawin dengan orang yang sangat dekat dalam kekeluargaan sedarah dank arena perkawinan;

2) larangan kawin karena zina;

3) larangan kawn untuk memperbarui perkawinan setelah adanya perceraian, jika belum lewat waktu satu tahun.

c. Syarat formal adalah syarat yang berkaitan dengan formalitas-formalitas dalam pelaksanaan perkawinan, syarat ini dibagi dalam dua tahapan yaitu:

1) Pemberitahuan tentang maksud kawin (Pasal 50 dan Pasal $51 \mathrm{KUH}$ Perdata), Pemberitauan disampikan kepada pegawai pencatat sipil.

2) Syarat-syaratyang harus dipenuhi bersamaan dengan dilangsungkannya perkawinan.

Apabila kedua syarat diatas, baik syarat intern dan syarat ekstern maupun syarat materiil dan formal sudah dipenuhi maka perkawinan itu sudah dapat dilangsungkan. Momentum suatu perkawinan dikatakan sah apabila telah dilangsungkan menurut hukum dan kepercayaan masing-masing dan di catat menurut Peraturan perundang-undangan (Pasal 2 UU No. 1 Tahun 1974). Tujuan diadakan ketetuan Pasal 2 ayat (1) Undang-Undang Nomor 1 Tahun 1974 adalah untuk menghindari konflik hukum antara hukum adat dan hukum agama, dan hukum antar golongan. Sedangkan tujuan pencatatan perkawinan adalah menjadikan peristiwa perkawinan menjadi jelas baik oleh yang bersangkutan maupun pihak lain, sebagai alat bukti bagi anak-anaknya kelak kemudian, 
apabila timbul sengketa baik diantara anak kandung maupun anak tiri, dan sebagai dasar pembayaran tunjangan istri atau suami bagi pegawai negeri sipil. ${ }^{14}$

Musdah Mulia menjelaskan dalam presefektif lain bahwa prinsip-prinsip perkawinan tersebut ada empat ada empat yang didasarkan pada ayat-ayat alQur'an. Diantaranya adalah: ${ }^{15}$

a. Prinsip kebebasan dalam memilih jodoh: Prinsip ini sebenarnya kritik terhadap tradisi bangsa Arab yang menempatkan perempuan pada posisi yang lemah, sehingga untuk dirinya sendiri saja ia tidak memiliki kebebasan untuk menentukan apa yang terbaik pada dirinya. Oleh sebab itu kebebasan memilih jodoh adalah hak dan kebebasan bagi laki-laki dan perempuan sepanjang tidak bertentangan dengan syari'at islam.

b. Prinsip mawaddah wa rahmah: Prinsip ini didasarkan pada firman Allah SWT QS ar-Rum:21. Mawaddah wa rahmah adalah karakter manusia yang tidak dimiliki oleh makhluk lainnya. Jika binatang melakukan hubungan seksual semata-mata untuk kebutuhan seks itu sendiri juga dimaksudkan untuk berkembang biak, sedangkan perkawinan manusia bertujuan untuk mencapai ridha Allah disamping tujuan yang bersifat biologis.

c. Prinsip saling melengkapi dan saling melindungi: Prinsip ini didasarkan pada firman Allah SWT yang terdapat pada surah al-Baqarah:187 yang menjelaskan istri-istri adalah pakaian sebagaimana layaknya dengan lakilaki juga sebagai pakaian untuk wanita. Perkawinan laki-laki dan perempuan dimaksudkan untuk saling membantu dan saling melengkapi, karena setiap orang memiliki kelebihan dan kekurangan.

d. Prinsip mu'asarah bi al-ma'ruf: Prinsip ini didasarkan pada firman Allah SWT yang terdapat pada surah an-Nisa:19 yang memerintahkan kepada setiap laki-laki untuk memperlakukan istrinya dengan cara yang ma"ruf. Didalam prinsip ini sebenarnya pesan utamanya adalah pengayoman dan penghargaan kepada wanita.

14 Ibid.

15 Siti Musdah Mulia, Islam Menggugat Poligami (Jakarta: Gramedia Pustaka Utama, 2004). 
4. Perspektif Undang-Undang Nomor 1 Tahun 1974 Tentang Perkawinan

Undang-Undang Nomor 1 Tahun 1974 tentang Perkawinan tidak mengenal adanya rukun perkawinan. Tampaknya Undang-Undang Perkawinan hanya memuat hal-hal yang berkenaan dengan syarat-syarat perkawinan. Didalam Bab II Pasal 6 ditemukan ayat-ayat perkawinan, sebagai berikut:

a. Perkawinan harus didasarkan atas persetujuan kedua calon mempelai;

b. Untuk melangsungkan perkawinan seorang yang belum berumur 21 tahun harus mendapat izin kedua orang;

c. Dalam hal salah seorang dari kedua orang tua telah meninggal dunia atau dalam keadan tidak mampu menyatakan kehendaknya, maka izin dimaksud ayat (2) pasal ini cukup diperoleh dari orang tua yang mampu menyatakan kehendaknya;

d. Dalam hal kedua orang tua telah meninggal dunia atau dalam keadaan tidak mampu untuk menyatakan kehendaknya maka izin diperoleh dari wali, orang yang memelihara atau keluarga yang mempunyai hubungan darah dalam garis keturunan lurus keatas selama mereka masih hidup dan dalam keadaan dapat menyatakan kehendaknya;

e. Dalam hal ada perbedaan pendapat antara orang-orang yang disebut dalam ayat (2), (3), dan (4) pasal ini, atau salah seorang lebih diantara mereka tidak menyatakan pendapatnya, maka pengadilan dalam daerah hokum tempat tinggal orang yang akan melangsungkan perkawinan atas permintaan orang tersebut dapat memberikan izin setelah terlebih dahulu mendengar orang-orang tersebut dalam ayat (2), (3), dan (4) dalam Pasal ini.

f. Ketentuan tersebut ayat (1) sampai dengan ayat (5) Pasal ini berlaku sepanjang hukum masing-masing agamanya dan kepercayaannya itu dari yang bersangkutan tidak menentukan lain.

Selanjutnya pada Pasal 7, terdapat persyaratan-persyaratan yang lebih rinci. Berkenaan dengan calon mempelai pria dan wanita, undang-undang 
mensyaratkan batas minimum umur calon suami sekurang-kurangnya berumur 19 tahun dan calon istri sekurang-kurangnya berumur 16 tahun.

C. Pernikahan Tanpa Persetujuan Salah Satu Pihak Dalam Perspektif Hukum Perdata Dan Hukum Islam di Kota Ternate: Kasus POLDA MALUT

1. Perspektif Hukum Perdata

Perkawinan menurut KUH Perdata yang memandang perkawinan hanya sebagi perbuatan keperdataan belaka (Pasal 26 KUHPerdata). Perkawinan menurut Undang-Undang Nomor. 1 Tahun 1974 bukan hanya sekedar perbuatan hukum yang menimbulkan akibat-akibat hukum, akan tetapi juga merupakan perbuatan keagamaan (ibadah), sehingga sah tidaknya suatu perkawinan ditentukan menurut hukum agama dan kepercayaan masing-masing yang melangsungkan perkawinan.

Berdasarkan penjelasan pasal tersebut disebutkan dengan perumusan pada Pasal 2 ayat (1) ini, tidak ada perkawinan di luar hukum masing-masing agamanya dan kepercayaannya itu, sesuai dengan UUD 1945. Yang dimaksud dengan hukum masing-masing agamanya dan kepercayaannya itu termasuk ketentuan perundang-undangan yang berlaku bagi golongan agamanya dan kepercayaannya itu sepanjang tidak bertentangan atau tidak ditentukan lain dalam Undang-undang ini.

Untuk menganalisis dari rumusan ketentuan Pasal 2 Undang-Undang Nomor. 1 Tahun 1974 dikutip di atas, bahwa sah tidaknya suatu perkawinan diukur dengan ketentuan hukum agama dan kepercayaan masing-masing orang yang melangsungkan perkawinan. Perkawinan sah apabila telah memenuhi semua syarat dan rukun hukum agamanya dan kepercayaannya itu. Pencatatan perkawinan hanyalah merupakan tindakan administratif, bukan menentukan sah tidaknya perkawinan. Pandangan seperti inilah yang dianut oleh umat Islam Indonesia.

Pernikaha Tanpa Persetujuan salah satu pihak atau melawan hukum dal Kitab Undang-Undang Hukum Perdata (KUHPerdata) berlaku asas pokok, bahwa tiada suatu perkawinan menjadi batal karena hukum. Pernyataan batal 
suatu perkawinan yang bertentangan dengan undang-undang disyaratkan adanya keputusan pengadilan, keputusan yang demikian hanya boleh dijatuhkan dalam hal-hal yang diatur oleh undang-undang dan atas gugatan orang-orang yang dinyatakan berwenang untuk itu. Hal ini sesuai dengan penjelasan dalam Pasal 85 ( KUHPerdata) sebagai berikut:

Pencatatan adalah perintah Undang-Undang Nomor. 1 Tahun 1974 sebagai perwujudan siasah Syar'iyyah dari pemerintah yang harus ditaati untuk terwujudnya kemaslahatan dan memenuhi tuntutan kehidupan umat yang terus berkembang demi kepastian hukum.

Sedangkan dalam Undang-Undang No. 1 Tahun 1974 seorang suami yang ingin menikah lagi harus memenuhi syarat alternatif dan syarat komulatif yang telah diatur oleh Undang-Undang tersebut. Adapun alasan-alasan yang dimaksud Undang-Undang No. 1 Tahun 1974 pasal 4 ayat 2 yaitu pertama, isteri tidak dapat menjalankan kewajibannya sebagai seorang isteri, kedua, isteri mendapat cacat badan atau penyakit yang tidak dapat disembuhkan, ketiga, isteri tidak dapat melahirkan keturunan. Di samping ketiga syarat tersebut, juga harus memenuhi syarat yang lain yaitu pertama, adanya persetujuan dari isteri/isteri-isteri, kedua, adanya kepastian bahwa suami mampu menjamin keperluankeperluan hidup isteri-isteri dan anak-anak mereka dan ketiga, adanya jaminan bahwa suami akan berlaku adil terhadap isteri-isteri dan anak-anak mereka.

Peraturan tentang perkawinan di Indonesia yang pada dasarnya menganut asas monogami, tetapi masih terbuka pintu lebar bagi seorang suami untuk melakukan poligami. Untuk melakukan poligami, suami yang ingin berpoligami salah satu syaratnya dapat izin isteri dan datang ke Pengadilan Agama untuk mendapatkan izin dari Pengadilan. Pasal 4 ayat 1 Undang-Undang No. 1 Tahun 1974. Bahwa dalam hal seorang suami akan beristeri lebih dari seorang, maka ia wajib mengajukan kepada Pengadilan didaerah tempat tinggalnya.

Menurut Undang - Undang No. 1 Tahun 1974 tentang Perkawinan dijelaskan dalam pasal 2 disebutkan bahwa : 1) Perkawinan adalah sah apabila dilakukan menurut hukum masing - masing agamanya dan kepercayaannya itu; 2) Tiap- 
tiap perkawinan dicatat menurut peraturan perundang - undangan yang berlaku. ${ }^{16}$ Dengan memahami pengertian perkawinan dalam hukum Islam dan undang-undang perkawinan dapat diambil kesimpulan bahwa perkawinan memiliki makna yang penting. Dengan demikian, suatu perkawinan tidak hanya suatu hubungan antara manusia dengan manusia, tetapi juga merupakan hubungan antara manusia dengan Tuhan sehingga hal inilah yang menjadikan perkawinan suatu peristiwa yang sangat sakral. Perkawinan tentu akan dipandang terhormat di dalam suatu masyarakat apabila didasarkan pada suatu ikatan cinta dan kasih sayang, dalam hal ini ikatan perkawinan tersebut merupakan ikatan yang paling teguh dan paling kuat disebabkan adanya rasa cinta dan kasih sayang antara laki - laki dan wanita secara timbal balik.

Dalam Kitab Undang-Undang Hukum Perdata tidak mengatur adanya perkawinan poligami karena asas dalam KUHPer adalah monogami. Seperti yang telah dijelaskan dalam Pasal 27 bab perkawinan disebutkan "dalam waktu yang sama seorang lakilaki hanya diperbolehkan mempunyai satu orang perempuan sebagai istrinya, seorang perempuan hanya satu orang laki-laki sebagai sumainya.

Secara yuridis formal, poligami di Indonesia diatur dalam Undang-undang Perkawinan No 1 Tahun 1974 tentang Perkawinan, Peraturan Pemerintah No 9 Tahun 1975 tentang Pelaksanaan Undang-undang No 1 Tahun 1974 tentang Perkawinan dan Kompilasi Hukum Islam (KHI) bagi penganut agama Islam. Walaupun pada dasarnya asas yang melekat dalam Undang-Undang perkawinan tersebut merupakan asas monogami. Namun menurut M. Yahya Harahap “asas hukum dalam Undang-undang tersebut tidaklah berimplikasi pada asas monogami mutlak akan tetapi asas monogami terbuka.

Sementara asas yang melekat pada Kompilasi Hukum Islam (KHI) adalah asas poligami tertutup. Sebab secara tersurat dalam Pasal 55 ayat (1) Kompilasi Hukum Islam (KHI) dijelaskan bahwa asas perkawinanya adalah poligami. Namun pasal-pasal setelahnya mengindikasikan untuk menutup asas poligami

16 Zainal Abidin Abubakar, Kumpulan Peraturan Perundang-Undangan Dalam Lingkungan Peradilan Agama (Jakarta: Yayasan Al-Hikmah, 2011). 
tersebut dengan berbagai persyaratan yang begitu ketat, sehingga tidak memungkinkan bagi para pelaku poligami untuk menerapkannya dengan sewenang-wenang.

Dalam perspektif HAM, izin isteri sebagai syarat untuk melakukan pernikahan merupakan hak individu yang perlu diperjuangkan, dalam hal ini perkawinan dipandang bukan hanya persoalan biologis semata akan tetapi juga merupakan persoalan psikologis, sosiologis, tapi ada sebagian di masyarakat yang berpoligami menggunakan tameng teologis/ agama, sekalipun orientasinya adalah murni biologis.

Perbuatan poligami diperbolehkan apabila telah memenuhi persyaratan sebagaimana disebutkan didalam Pasal 3 ayat (3), Pasal 4 dan Pasal 5 UUP. Apabila ketentuan tersebut dilanggar maka pelaku poligami ilegal diancam dikenakan sanksi pidana kategori pelanggaran sebagaimana diatur Pasal 45 Peraturan Pemerintah Nomor 9 Tahun 1975.

Ketentuan sanksi pidana yang diatur didalam Pasal 45 Peraturan Pemerintah Nomor 9 Tahun 1975 merupakan peristiwa pidana yang digolongkan kepada jenis pidana pelanggaran (contraventions) bukan peristiwa pidana yang digolongkan kepada kejahatan ringan (rechtsdeliktern). Ancaman Sanksi bagi Pelaku yang melanggar ketentuan Pasal 3, 10 ayat (3) dan Pasal 40 PP No 9 tahun 1975 inipun tergolong ringan yaitu hanya sanksi dengan ancaman denda setinggi-tinggi Rp. 7.500.- (tujuh ribu lima ratus rupiah). UUP juga mengatur mengenai hal-hal yang menjadi penghalang bagi seorang suami yang ingin berpoligami yang terdapat dalam Pasal 9, 15 dan, 24 yaitu sebagai berikut: 1. Pasal 9 UUP yang berbunyi "Seseorang yang masih terikat tali perkawinan dengan orang lain tidak dapat kawin lagi kecuali hal yang tersebut pada Pasal 3 Ayat (2) dan Pasal 4 undang-undang ini; 2. Pasal 15 UUP yang berbunyi "Barangsiapa karena perkawinan dirinya masih terikat dengan salah satu dari kedua belah pihak dan atas dasar masih adanya perkawinan yang dapat mencegah perkawinan yang baru"; 3. Pasal 24 UUP yang berbunyi "Barangsiapa karena perkawinan masih terikat dirinya dengan salah satu pihak dan atas dasar masih adanya perkawinan dapat mengajukan pembatalan perkawinan. 
Selanjutnya Pada Pasal 45 Peraturan Pemerintah Nomor 9 Tahun 1975 Tentang Perkawinan menyebutkan bahwa Barang siapa yang melanggar ketentuan yang diatur dalam Pasal 3, 10 ayat (3), 40 Peraturan Pemerintah ini dihukum dengan hukuman denda setinggitingginya Rp.7.500,-(tujuh ribu lima ratus rupiah). Ketentuan Pasal 40 yang dimaksud pada Pasal 45 Peraturan Pemerintah Nomor 9 Tahun 1975 adalah “Apabila seorang suami bermaksud untuk beristeri lebih dari seorang maka ia wajib mengajukan permohonan secara tertulis kepada Pengadilan.

Ketentuan Pasal 45 atas pelanggaran terhadap Pasal 40 dimaksud berkaitan dengan ketiadaan izin poligami dari Pengadilan, sehingga perbuatan poligami yang dilakukan secara liar (tanpa izin pengadilan) dapat dikenakan sanksi pidana berupa membayar denda setinggi- tingginya Rp.7.500,-(tujuh ribu lima ratus rupiah).

Dari unsur-unsur pasal dimaksud dapatlah diketahui bahwa larangan terhadap poligami bukan terletak kepada hukum pernikahannya, tapi terletak kepada syarat administrasi yang harus terpenuhi terlebih dahulu yang dibuktikan dengan adanya penetapan dari pengadilan. Unsur-unsur yang terdapat didalam Pasal 45 PP Nomor 9 Tahun 1975 tidak jauh berbeda dengan rumusan pasal yang terdapat Draft RUU Hukum Materil Pengadilan Agama.

Ketentuan Pasal 145 Draft RUU HMPA me - nyebutkan bahwa “Setiap orang yang melangsungkan perkawinan dengan isteri kedua, ketiga atau keempat tanpa mendapat izin terlebih dahulu dari Pengadilan sebagaimana dimaksud dalam Pasal 52 ayat (1) dipidana dengan pidana denda paling banyak Rp. 6.000.000,- (enam juta rupiah) atau hukuman kurungan paling lama 6 (enam) bulan". Dengan demikian berdasarkan redaksi Pasal 145 Draft RUU HMPA dapatlah diketahui bahwa perbuatan poligami sama sekali tidak dilarang selama suami yang ingin berpoligami mendapatkan izin dari pengadilan. Perbuatan poligami yang dilakukan secara illegal (tanpa izin pengadilan) dapat dikenakan sanksi pidana berupa delik pidana pelanggaran dengan sanksi yang sedikit lebih tinggi dari ketentuan Pasal 45 PP Nomor 9 Tahun 1975 yaitu membayar denda 
paling banyak Rp. 6.000.000,- (enam juta rupiah) atau hukuman kurungan paling lama 6 (enam) bulan.

2. Poligami tanpa Persetujuan Salah Satu Pihak Dalam Perspektif Hukum Hukum Islam di Kota Ternate: Kasus POLDA MALUT.

Menurut Hukum Islam, akad perkawinan suatu perbuatan hukum yang sangat penting dan mengandung akibat-akibat serta konsekuensikonsekuensinya tentu sebagaiman yang telah ditetapkan oleh syariat Islam. Pelaksanaan akad pernikahn yang tidak sesuai dengan ketentuan yang telah ditetapkan oleh syariat Islam adalah perbuatan yang sia-sia, bahkan dipandang sebagai perbuatan yang yang melanggar hukum yang wajib dicegah oleh siapapun yang mengetahuinya, atau dengan cara pembatalan apabila pernikahan itu telah dilaksanakannya. ${ }^{17}$

Batal yaitu rusaknya hukum yang ditetapkan terhadap suatu amalan seseorang, karena tidak memenuhi syarat dan rukunnya, sebagaimana yang ditetapkan oleh syara". Batalnya perkawinan yaitu "rusak atau tidak sahnya perkawinan karena tidak memenuhi salah satu syarat atau salah satu rukunnya, atau sebab lain yang dilarang atau diharamkan oleh agama. Batalnya perkawinan atau putusnya perkawinan disebut juga dengan fasakh. Fasakh bisa terjadi karena tidak terpenuhinya syarat-syarat ketika berlangsung akad nikah, atau karena hal-hal lain yang datang dan membatakan perkawinan. ${ }^{18}$ Dimaksud memfasakh akad nikah adalah memutuskan atau membatalkan ikatan hubungan antara suami dan istri. ${ }^{19}$

Pisahnya suami istri akibat fasakh berbeda dengan pisahnya karena talak. Sebab talak ada rajei dan talak ba ${ }^{e} i n$. Talak rajeci tidak mengakhiri ikatan suami istri dengan seketika, sedangkan talak ba ${ }^{e} i n$ mengakhirinya seketika itu juga. Adapun fasakh, baik karena hal-hal yang terjadi belakangan ataupun karena

\footnotetext{
17 Ahmad Rofiq, Hukum Perdata Islam Di Indonesia (Jakarta: PT. Raja Grafindo Persada, 2013).

18 Abdul Manan, Aneka Masalah Hukum Perdata Islam Di Indonesia (Jakarta: Kencana, 2006).

${ }^{19}$ Khoirul, Hukum Perkawinan Dan Perceraian.
} 
adanya syarat-syarat yang tidak terpenuhi, ia mengakhiri perkawinan seketika itu. ${ }^{20}$

Menurut ketentuan hukum Islam, siapa yang melihat dan mengetahui akan adanya seorang berkehendak untuk melangsungkan pernikahan, padahal diketahui bahwa pernikahan cacat hukum karena kurangnya rukun atau syarat yang ditentukan, maka pernikahan tersebut wajib dicegah sehingga perkawinan itu tidak jadi dilaksanakan. Jika mengetahui setelah akad nikah dilaksanakan, maka wajib mengajukan pembatalan kepada instansi yang berwenang. Pembatalan perkawinan berlaku terhadap segala bentuk perkawinan yang tidak sah, baik yang bersifat nikōh bathil. Maupun yang bersifat nikōh fasid, baik sebelum terjadi persetubuhan maupun sesudah terjadi persetubuhan. Agar tidak terjadi wāthiee syūbhat antara suami istri yang melaksanakan perkawinan yang tidak sah itu, maka seketika diketahui perkawinan tersebut adanya cacat hukum, kepada suami- istri tersebut dilarang berkumpul lebih dahulu sambil menunggu penyelesaian perkaranya diselesaikan oleh pihak yang berwenang. ${ }^{21}$

Pelaku poligami yang tidak mengantongi izin dari pengadilan agama merupakan perbuatan yang melawan hukum, sedangkan orang yang menikahkan pelaku poligami juga turut serta melakukan perbuatan melawan hukum yang dapat juga dikenakan sanksi pidana.

Menurut hukum pidana Islam apabila perbuatan langsung (pelaku poligami) berkumpul dengan perbuatan tidak langsung (orang yang menikahkah) dalam suatu tindak pidana maka keduanya ada 3 kemungkinan:22

1. Perbuatan tidak langsung lebih kuat daripada perbuatan langsung Hal ini terjadi apabila perbuatan langsung bukan perbuatan yang berlawanan dengan hukum, seperti persaksian palsu yang mengakibatkan adanya putusan hakim untuk menjatuhkan hukuman mati atas diri tersangka, dalam contoh ini persaksian palsu adalah perbuatan tidak langsung.

20 Slamet Abidin and Aminuddin, Fiqih Munakahat II (Bandung: Pustaka Setia, 2009).

${ }^{21}$ Ayyub Syaikh Hasan, Fikih Keluarga (Jakarta: Pustaka Al-Kautsar, 2004).

22 Ahmad Wardi Muslih, Pengantar Dan Asas Hukum Pidana Islam (Jakarta: Sinar Grafika, 2006). 
2. Perbuatan langsung lebih kuat daripada perbuatan tidak langsung Hal ini terjadi apabila perbuatan langsung dapat memutus daya kerja perbuatan tidak langsung, dan perbuatan tidak langsung itu sendiri tidak mengharuskan menimbulkan akibat yang terjadi, seperti orang yang menjatuhkan orang lain ke dalam jurang, kemudian datang orang ketiga yang membunuh orang dalam jurang tersebut.

3. Kedua perbuatan tersebut seimbang Hal ini terjadi apabila daya kerjanya sama kuatnya, seperti orang yang memaksa orang lain untuk melakukan perbuatan yang melanggar hukum. Dalam contoh ini orang yang memaksa itulah yang menggerakkan pembuat langsung untuk melakukan perbuatan melanggar hukum itu, sebab kalau tidak ada orang yang memaksa, tentunya orang kedua tidak akan berbuat. Akan tetapi kalau sekiranya tidak ada orang kedua belum tentu paksaan orang pertama tadi akan menimbulkan perbuatan melanggar hukum tersebut.

Keikutsertaan orang yang menikahkan pelaku poligami ilegal menurut Imam Malik, "Ia menganggap orang yang bersepakat dengan orang lain untuk melakukan suatu tindak pidana dan orang tersebut menyaksikan tindak pidana itu berlangsung, orang tersebut dianggap sebagai "pelaku penyerta langsung" (mede dader), bukan pelaku tidak langsung. Demikianlah teori Imam Malik mengenai pelaku tidak langsung secara mutlak, baik sarana, cara mewujudkan perbuatan tidak langsung tersebut melalui persepakatan, penghasutan, atau bantuan

Orang yang dianggap pelaku tidak langsung ialah setiap orang yang bersepakat dengan orang lain untuk melakukan suatu perbuatan yang dapat dijatuhi hukuman atasnya, orang yang menghasut (menggerakkan) orang lain atau membantu dalam perbuatan tersebut, dengan disyaratkan adanya kesengajaan dalam kebersepakatan, penghasutan, dan pemberian bantuan tersebut. $^{23}$

Menurut Imam Abu Hanifah dan Imam Syafiei, orang yang turut serta tersebut adalah orang yang memberikan bantuan (pelaku tidak langsung), bukan

${ }^{23}$ Ahsin Sakho Muhammad, Ensiklopedi Hukum Pidana Islam (Bogor: Kharisma Ilmu, 2005). 
pelaku langsung. Alasannya adalah karena perbuatan langsung, yaitu pelaku poligami lebih kuat daripada perbuatan tidak langsung. Imam Malik berpendapat bahwa "apabila orang yang menghasut turut menyaksikan dan berada di tempat kejadian perkara pada saat tindak pidana itu berlangsung, ia dianggap sebagai pelaku asli, baik ia turut membantu pelaku langsung maupun tidak, dengan syarat sekiranya pelaku langsung tidak melakukan tindak pidana tersebut, ia sendiri yang melakukannya. ${ }^{24}$ Unsur-unsur keturutsertaan tidak langsung ada tiga, yaitu: 25

1. Perbuatan yang dapat dijatuhi hukuman pidana.

2. Sarana cara mewujudkan perbuatan tersebut, yaitu mengadakan persepakatan (permufakatan), penghasutan, atau pemberian bantuan.

3. Niat dari pelaku tidak langsung agar perbuatan yang dimaksudkan dapat terjadi.

Adakalanya suatu perbuatan jarimah dilakukan oleh lebih dari seorang secara tawafuq dan ada juga secara tamalu'. Perbuatan jarimah yang dilakukan secara tawafuq adalah perbuatan jarimah yang dilakukan oleh lebih dari seorang tanpa direncanakan dan disepakati sejak awal. Mereka secara tibatiba melakukan jarimah secara sendiri-sendiri. Misalnya, beberapa orang melakukan unjuk rasa. Tanpa disepakati sejak awal, mereka melakukan tindakan anarkis. Di antara mereka ada yang melakukan pembakaran kendaraan; melakukan pemukulan kepada aparat; merusak sarana umum; bahkan ada yang membunuh. ${ }^{26}$

Sedangkan perbuatan jarimah yang dilakukan secara tamalu' adalah perbuatan jarimah yang dilakukan oleh lebih dari seorang, direncanakan, dan disepakati sejak awal. Mereka bekerja sama melakukan jarimah secara langsung sesuai dengan kesepakatan. Misalnya, orang yang menikahkah melaksanakan perkawinan poligami. Mereka memiliki tugas masing-masing. mereka harus bertanggungjawabkan perbuatan jarimah secara keseluruhan. ${ }^{27}$

\footnotetext{
24 Ibid.

${ }^{25}$ Ahmad Hanafi, Asas-Asas Hukum Pidan Islam (Jakarta: Bulan Bintang, 2005).

${ }^{26}$ Muslih, Pengantar Dan Asas Hukum Pidana Islam.

27 Ibid.
} 
Hal ini dapat diartikan bahwa melakukan, menyuruh melakukan atau turut melakukan, serta memberi atau menjanjikan sesuatu bahwa suatu tindak pidana atau kejahatan yang dilakukan oleh lebih dari satu orang dengan cara bersamasama. Hal ini terkait dengan pertanggungjawaban, deeleming menurut sifatnya. Perbuataan penyertaan dapat di pidana hukuman pidana karena undang-undang memberi hak kepada orang yang melakukan keikut sertaan atau keajakan keikut sertaan dalam segala bentuk kejahatan. Sifat melawan hukum dari pada peristiwa yang dilakukan seperti di atas yang menjadi dasar pembenaran adanya pemidanaan. Sebaliknya dari pada penyertaan yang mengakibatkan adanya sifat melawan hukum dari perbuatan tersebut, dalam keikut sertaan yang melampaui batas perbuatan itu tetap melawan hukum. Alasan untuk dapat dipidana ialah keberadaan pihak kedua baik secara langsung maupun tidak langsung dalam kejahatan itu. Ini merupakan alasan untuk dipidananya atas kesalahan yang dilakukan dan bukan alasan yang menyulitkan.

Bahwa dalam hukum pidana Islam dan Kitab Undang-Undang Hukum Pidana mempunyai persamaan tentang Doenpleger. Dalam Hukum Pidana Islam disebut dengan pelaku tidak langsung yaitu merupakan suatu tindak pidana (jarimah) baik selesai maupun belum selesainnya tindak pidana, sama-sama dijatuhi hukuman dan perbedaannya adalah mengenai kedudukan orang yang menyuruhlakukan.

Dalam jarimah ta ${ }^{\mathrm{e}}$ zir tidak ada perbedaan pelaku poligami dan orang yang menikahkan pelaku poligami mendapat hukuman yang sama antara pelaku langsung adan pelaku tidak langsung, sebab perbuatan masing-masing pembuat tersebut termasuk jarimah ta ${ }^{\text {ee } z i r ~ d a n ~ h u k u m a n n y a ~ j u g a ~ h u k u m a n ~ t a ~}{ }^{\text {ee } z i r . ~}$ Sedangkan syara"e tidak memisahkan antara jarimah ta"zir yang satu dan jarimah ta ${ }^{\mathrm{ee}}$ zir lainnya. Selama hakim mempunyai kebebasan dalam menentukan besar kecilnya hukuman ta ${ }^{\text {ee } z i r, ~ m a k a ~ t i d a k ~ a d a ~ p e r l u n y a ~ m e m b u a t ~ p e m i s a h a n ~ a n t a r a ~}$ hukuman perbuatan langsung dengan hukuman perbuatan tidak langsung dalam jarimah ta"eir. Oleh sebab itu, hukuman bagi orang yang menikahkan pelaku poligami bisa lebih berat, sama berat atau lebih ringan dari pada 
hukuman pelaku poligami, berdasarkan pertimbangan masing-masing pelaku, baik keadaannya maupun perbuatannya.

Berdasarkan analysis hukum pidana Islam terhadap orang yang menikahkan pelaku poligami tanpa izin Pengadilan Agama dapat dikatagorikan perbuatan melanggar hukum, masuk dalam katagori jarimah ta ${ }^{\text {ee } z i r, ~ y a n g ~ m a n a ~}$ hukumannya diserahkan kepada penguasa untuk memutuskan hukuman apa yang pantas diberikan kepada orang yang menikahkan pelaku poligami tanpa izin Pengadilan Agama. Hakim diberi wewenang yang luas dalam menjatuhkan hukuman dengan berpedoman kepada batas maksimal dan minimal yang telah ditetapkan oleh pemerintah yang sah. Ta"e zir dapat juga mengalami perubahan sesuai dengan perubahan masyarakat.

3. Penyelesaian Hukum Terhadap Kasus Pernikahan Tanpa Persetujuan salah satu pihak pada POLDA Maluku Utara dan Pengadilan Agama Kota Ternate

Negara Republik Indonesia merupakan negara hukum, dan poligami merupakan hal yang telah diatur di dalam Undang-Undang terhadapat dalam UU Perkawinan yang memberikan pengecualian, pada pasal 3 ayat (2) UU Perkawinan yang mana pengadilan dapat memberikan izin kepada seorang suami untuk beristri lebih dari seorang apabila dikehendaki oleh pihak-pihak yang bersangkutan.

a. Penyelesaian Hukum Terhadap Kasus Pernikahan Tanpa Persetujuan salah satu pihak pada POLDA Maluku Utara

Prosesi perkwian yang dilakukan oleh seorang suami menikah lagi dengan wanita lain tanpa ada izin tanpa meminta izin kepada istri pertama terlebih dahulu (selaku isteri pertama). Maka susmi tersebut mendapatkan hukuman sanksi pidana terhadap laki-laki yang menikah tersesebut tanpa ada izin dari isteri terdahulu Terhadap suami yang menikah lagi tanpa izin dari isteri pertama.

Berdasarkan peristiwa perkawinan yang melanggar hukum dengan aturan yang mengatur mengenai suami menikah secara diam-diam tanpa diketahui istri pertama, maka suami tersebut telah melakukan pelanggaran hukum. 
Peristiwa ini telah dialami oleh salah satu korban wanita, membuat laporan polisi untuk dilaporkan ke Polda Maluku Utara agar bisa di Proses Hukum. Ketika peneliti melakukan wawnacar kepada Penyidi di Polda Maluku Utara, Dalam wawancaranya penydidik meyampaikan hasil lapaoran dari si korban sebagai berikut:

Suami saya secara diam-diam menikah lagi dengan wanita simpananya,dalam pelaksanaan pernikahan tersebut tidak pernah meminta izin atau memberitahukan, dan rumah tangga kami pada awalnya berjalan aman damai seperti biasanya, karena saya beranggapan tidak ada masalah sama sekalih, dalam rumah tangga kami sekeluarga, hidup rukun. Namun menjelang beberapa minggu kemudian ada perubahan yang terjadi pada suami saya, disela-selah aktifitas siang dan malam, tidak seperti biasanya, sering pulang larut malam, bahkan sampai pagi, dan bermingumingou, kami bersama anak-anakpun bertanya-tanya, dan pada akhirnya ketahuan permasalahan yang dilakukan oleh suami saya. Dan terjadilah pertengakaran dalam rumah tangga kami berunjung perkelahian, dan peristiwa ini diaporkan ke Polda Maluku Utara.

Dalam Peristiwa seorang suami menikah tanpa meminta izin istri pertam, korban bersama kuasa hukumnya mendatangi ke Polda Maluku Utara untuk membuat aduan laporan polisi, dan kami menerima, untuk menyeleasaikan permohonan aduan tersebut hal ini berdasarkan tugas dan tanggung jawab kami, yantg telah diatur Dalam Pasal 15 rangka menyelenggarakan tugas sebagaimana dimaksud dalam Pasal 13 dan 14 Kepolisian Negara Republik Indonesia Undang-undang nomor 2 tahun 2002 tentang kepolisian pada pasal 14 huruf a. secara umum berwenang Menerima laporan dan/atau pengaduan.

Dalam kasus tersebut kami telah menerima laporan dan memepelajari isi laporan tersebut, dengan mengahadirkan korban dan saksi maupun buktibukti lain demi kelancaran proses peyedidikan kami terhadap, permasalah tersebut setelah dipelajari samapai selesai, dikelurakan surat pemanggian kepada yang besangkutan dan ditahan di Polda Maluku Utara.

Proses Penahanan pelaku yang mealukan pernikahan tanpa persetujuan dari seorang istri pertama ini, untuk kepentingan penyidikan, penyidik atau penyidik pembantu atas perintah penyidik berwenang maka polisi boleh melakukan penahan terhadap tersangka untuk kepentingan penyidikan dan karena di khawatirkan tersangka melarikan diri, atau menghilangkan barang 
bukti dan atau mengulangi kembali tindak pidana yang serupa proses penahan yang dilakukan oleh penyidik hanya berlaku paling lama 20 hari (Pasal 24 Ayat 1 Undang-undang Nmor.8 Tahun 1981 tentang Kitab UndangUndang Hukum Acara Pidana), namun apabila diperlukan guna kepentingan pemeriksaan yang belum selesai, maka diperpanjang oleh penuntut umum yang berwenang paling lama 40 hari (Pasal 24 Ayat 2 Undang-undang Nmor.8 Tahun 1981 tentang Kitab Undang-Undang Hukum Acara Pidana). Pembuatan BAP (Berita Acara Pidana) Setelah Peyidik Polda Maluku Utara melakukan penangkapan, penyelidikan, penyidikan, dan penahanan maka polisi membuat BAP (Berita Acara Pidana) yang diserahkan kepada pihak kejaksaan, sehingga untuk selanjutnya penyidikan dilakukan oleh Pihak Kejaksaan.

Dalam proses Peyidik Polda Maluku Utara melakukan penangkapan, penyelidikan, penyidikan, dan penahanan dan terbukti mencukupi bukti maka perkara ini diserahak kejaksaan Tinggi Maluku Utara melakukan penyelidikan, penyidikan dan telah memenuhi syarat cukup bukti, dapat dilakukan proses penuntutan umum terhadap pelaku tersebut, dan Hakim Pengadialan memutuskan berdasarkan aturan yang berlaku, dan serahak ke pihak kejakasaan untuk dieksekusi dalam penjara sesuai hukuman yang di putuskan.

Dalam kasus perkwaninan yang dilakukan seorang suami tanpa peresetjuan seorang Istri di Polda Maluku Utara. Peneliti melakukan wawancara kepada Peyidik yang menangani kasus Pernikahan tanpa izin seorang Istri, penyampaian yang disamapaikan oleh penyidik yaitu:

Kami telah menyelesaikan 6 kasus yang terdiri dari tahun 20171 Kasus, yang telah serahakan dan diputuskan oleh Jaksa dan Hakim, pada tahun 2018 juga 1 kasus yang sama, dan diproses sampai penjatuhan hukuman oleh hakim, di tahun 2019 terdapat 4 kasus yang sama juga, semuanya telah diputuskan masuk penjara berdasarkan putusan Hakim. Dalam penyelidikan terhadap 6 orang tersebut hampir mirip-mirip dalam melaksanakan pernikahan tersebut, dari mereka 6 orang tersebut semua memiliki jabatan dan mempunyai usaha, dengan modal kekayaan itulah sebagai jalan untuk melakukan segalah cara dalam melawan hukum.

Kitab Undang-Undang Hukum Pidana (KUHP), dengan ancaman pidana maksimal 5 sampai 7 tahun penjara. jika seorang suami yang kawin lagi tanpa 
izin pengadilan, maka terhadapnya harus diterapkan ketentuan pidana dalam Pasal 279 ayat (1) ke 1 KUHP, yaitu ancaman pidana selama lima tahun, terhadapnya tidak dapat diancam pidana menurut ketentuan Pasal 45 ayat (1) PP No. 9 Tahun 1975, karena yang diatur secara khusus dalam PP tersebut adalah pelanggaran ketentuan administrasi perkawinan, tidak mengatur secara khusus mengenai ancaman pidana bagi suami yang kawin lain padahal perkawinannya yang sudah ada menjadi halangan sah baginya untuk kawin. Ketentuan sanksi pidana atas perbuatan yang diatur di dalam Pasal 279 Kitab Undang-undang Hukum Pidana (KUHP). Ketentuan Pasal 279 Kitab Undangudang Hukum Pidana memandang perbuatan poligami ilegal yang telah ditetapkan oleh Undang-undang sebagai perbuatan pidana kategori kejahatan ringan (rechtsdeliktern) yang dapat diancam sanksi pidana. Pasal 279 ayat (1) KUH-Pidana menjelaskan sebagai berikut, diancam dengan pidana penjara paling lama lima tahun:

1) Barang siapa mengadakan perkawinan padahal mengetahui bahwa perkawinan atau perkawinan-perkawinannya yang telah ada menjadi penghalang yang sah untuk itu;

2) Barang siapa mengadakan perkawinan padahal mengetahui bahwa perkawinan atau perkawinan-perkawinan pihak lain menjadi penghalang untuk itu.

Jika disimak keberadaan Pasal 55 ayat 1 KUHP, maka ada keharusan untuk menemukan peran pelaku dan para pelaku dimintai pertanggungjawabannya sesuai dengan peranannya masingmasing. Artinya dalam prinsip deelneming tidaklah bisa semua pelaku adalah sama-sama sebagai orang yang melakukan, atau sama-sama sebagai orang yang menyuruh lakukan, apalagi sama-sama sebagai turut serta melakukan. Dalam konteks ini, suatu peristiwa pidana yang pelakunya lebih dari satu orang meminta adanya penemuan dari penegak hukum untuk menemukan kedudukan dan peran dari masing-masing pelaku. Dalam suatu peristiwa pidana adalah sangat penting menemukan hubungan antar pelaku dalam menyelesaikan suatu tindak pidana, yakni bersama-sama melakukan tindak 
pidana; Seorang mempunyai kehendak dan merencanakan kejahatan sedangkan ia menggunakan orang lain untuk melaksanakan tindak pidana tersebut. Seorang saja yang melakukan suatu tindak pidana, sementara orang lain membantu melaksanakan tidak pidana tersebut. Secara garis besar bisa dikelompokan, penyertaan bisa berdiri sendiri, mereka yang melakukan dan turut serta melakukan. Tanggung jawab pelaku dinilai sendiri-sendiri atas perbuatan yang dilakukan. Penyertaan bisa juga dalam arti tidak berdiri sendiri, pembujuk, pembantu dan yang menyuruh untuk melakukan suatu tindak pidana. Bila diperhatikan rumusan Pasal 55 tersebut, maka adalah tidak mungkin dalam pembuktian Pasal 55 KUHP dalam pemeriksaan perkara pidana, pasal ini dinyatakan sebagai terbukti hanya dengan menyimpulkan adanya kerjasama kolektif tanpa menunjukkan peran dari masing-masing pelaku dari suatu tindak pidana. Apalagi diantara pelaku terdapat hubungan kerja atasan dan bawahan dan disisi lain ada kewenangan-kewenangan dari hubungan atasan-bawahan dimaksud. Bahwa suatu tindak pidana yang pelakunya lebih dari satu orang, apalagi diberkas dalam satu perkara, maka jadi aneh apabila hanya dengan menyebutkan adanya kerjanya secara kolektif disimpulkan pasal 55 KUHP sebagai terbukti, padahal peran dan kedudukan dari masing-masing pelaku tidak ditemukan, misalnya manakah diantara pelaku tindak pidana yang ditempatkan sebagai orang yang melakukan, menyuruh lakukan atau iku melakukan. Dalam konteks ini betapa penting menemukan kapasitas dari masing-masing pelaku tindak pidana, apalagi terkait dengan hubungan kerja formal. Bahkan tidak jarang terjadi pembuktian Pasal 55 KUHP hanya dengan menguraikan kronologi peristiwa pidana dan mengabaikan peran dan kapasitas pelaku, hakim terkadang sampai pada kesimpulan bahwa Pasal 55 KUHP sudah terbukti. Padahal dengan menguraikan kronologi belumlah cukup untuk sampai pada kesimpulan dan memang hanya bisa sebatas menyatakan adanya kerjasama secara kolektif. Dalam konteks inilah acap seorang terdakwa dirugilkan hak pembelaan dirinya atas penyimpulan pasal 55 KUHP yang dangkal dan sederhana. Bahkan tidak sesuai dengan esensi yang terkandung dalam pasal 55 KUHP. 
Dengan demikian seorang pelaku poligami dapat dikenakan sanksi dengan kesalahan yang dibuatnya tergantung Pasal berapa yang akan dikenakan oleh hakim. Hal tersebut tergantung dari sudut pandang hakim dalam menjatuhkan pidana kepada pelaku poligami liar. Setelah pelaku dikenakan sanksi barulah orang yang menikahkah (penghulu) dapat dikenakan sanksi hukum sebagimana termaktub di dalam Pasal 55 KUHP penyertaan melakukan perbuatan tindak pidana.

b. Penyelesaian Hukum Terhadap Kasus Pernikahan Tanpa Persetujuan salah di Pengadilan Agama Kota Ternate

Poligami yang dilakukan tanpa izin istri dan pengadilan Agam Kelas 1B Kota Ternate, secara hukum suami yang menikah lagi dan mendapakan izin istri tidak dibenarkan dan merupakan pelanggaran hukum. Dan akibat hukum perkawinan yang dilakukan tanpa izin istri pertama (terdahulu) merupakan batal demi hukum atau dianggap tidak pernah ada. Jadi jelas bahwa bila suami ingin menikah lagi maka wajib mendapakan izin terlebih dahulu dari istri pertama atau istri-istri terdahulu, bila tidak mendapkan izin, maka secara hukum pernikahan itu merupakan cacat menurut hukum sehingga batal demi hukum.

Pembatalan perkawinan adalah pembatalan hubungan suami istri sesudah dilangsungkan akad nikah. Oleh karena itu, akan dikaji mengenai langkahlangkah Pembatalan setelah perkawinan selesai dilangsungkan, dan diketahui adanya syarat-syarat yang tidak terpenuhi menurut Pasal 22 Undang-Undang Perkawinan.

Apabila seorang suami sudah menikah lagi atau berpoligami tanpa sepengatuan dari istri pertama, maka istri pertama dapat menuntut dengan mengajukan permohonan pembatalan pernikahan yang terdapat didalam pasal 22-29 Undang-Undang Perkawinan. Pembatalan perkawinan hanya dapat dilakukan dengan putusan pengadilan, sehingga dengan adanya putusan pengadilan sebuah perkawinan yang sudah terjadi dianggap tidak pernah ada. Namun meskipun perkawinan itu sudah di anggap tidak pernah 
ada, tidak serta merta menghilangkan akibat hukum dalam perkawinan yang pernah dilakukan.

Pembataan perkawinan tentu dapat dipastikan masuk dalam area hukum acara atau hukum formal sehingga lahir suatu putusan pengadilan. Karena putusan pengadilan ini merupakan peristiwa hukum akibat dari perbuatan hukum terhadap suatu perkawinan orang lain, bukan putusan terjadina perceraian. Perbuatan hukum yang dimaksud ini merupan pengajuan permohonan pembatalan perkawinan yang diajukan oleh pihak yang mempunyai hak sebagaimana ditentukan dalam pasal 23 Undang-undang Nomor. 1 Tahun 1974 ditegaskan bahwa yang dapat mengajukan pembatalan perkawinan yaitu:

1) Para keluarga dalam garis keturunan lurus keatas dari suami dan isteri.

2) Suami isteri.

3) Pejabat yang berwenang hanya selama perkawinan belum diputuskan.

4) Pejabat yang diunjuk tersebut ayat (2) pasal 16 Undang-Undang ini dan setiap orang yang mempunyai kepentingan hukum secara langsung terhadap perkawinan tersebut, tetapi hanya setelah perkawinan itu putus.

Menurut Pasal 22 Undang-Undang perkawinan, yang menyatakan bahwa pembatalan perkawinan dapat dilakukan, bila para pihak tidak memenuhi syarat melangsungkan perkawinan, namun bila rukun yang tidak terpenuhi berarti pernikahan yang tidak sah.

Pada dasarnya suatu perkawinan dikatakan batal (dibatalkan) apabila perkawinan itu tidak memenuhi syarat-syarat sesudah dianjurkan kepengadilan. Dalam memutus permohonan pembatalan perkawinan, pengadilan harus selalu memperhatikan ketentuan agama mempelai. Jika menurut agamanya perkawinan itu sah maka pengadilan tidak bisa membatalkan perkawinan. Dalam Pembatalan perkawinan tesesbut peneliti telah melakukan wawancara kepada salah satu Hakim Pengadilan Agama 
Kelas 1B Kota Ternate yakni Ibu Umi Kalsum Abd. Kadir, S.HI., MH. Mengatakakan sebagai berikut:

Bahwa apabila telah terjadi poligami tanpa izin seorang Istri dan pengadilan Agama Setempat, sebagaimana yang diatur dalam pasal pasal 3 ayat 2 Undangundang Nomor 1 tahun 1974 Tentang Perkawinan, maka dapat dp Proses pembatalan perkawinan sama dengan tata cara gugatan perceraian, baik itu pemanggilan, pemeriksaan dan putusan pembatalan pernikahan perkawinan poligami, sebagaimana yang diatur dalam pasal 20 sampai 306 PP No. 9 Tahun 1975. Pembatalan perkawinan yang di lakukan oleh istri terhadap suami yang menikah lagi tanpa izin istri, tidak ada batas waktunya dalam melakukan proses pembatalan perkawinan dan kapanpun istri dapat mengajukan permohonan pembatalan perkawinan.

Berdasarkan hasil wawancara kepada Hakim Pengadilan Agama, terhadap proses pembatalan perkawinan tanpa izin seorang istri ( Poligami), dengan mengikuti prosedur aturan yang berlaku. Ibu Hakim pun menambahakan meskipun ini adalah peristiwa dalam perkara perdata pada dasarnya, namun telah mengandung unsur pidana, karena poligami tanpa izin seorang istri merupakan mengandung unsur peristiwa melawan hukum, karena melanggar Ketentuan Undang-Undang Perkawinan dan termasuk unsur penipuan yang dialukan oleh seorang pelaku tersebut.

Dalam pernikhan tanpa seiijin istri pertama maka seorang hakim Agama harus memperhatikan hak-hak isteri dalam hal suami berpoligami. Upayaupaya yang dilakukan hakim untuk melindungi hak isteri dalam hal suaminya akan berpoligami, yaitu: (a) Hakim memanggil isteri maupun calon isteri untuk dimintai pernyataan tentang kesediaannya untuk dimadu dan memberi penjelasan mengenai risiko suami berpoligami, selanjutnya pernyataan tersebut dituangkan dalam bentuk tertulis; (b) Hakim akan meminta saudara kandung isteri yang akan dimadu agar hadir di persidangan untuk memberikan keterangan dalam hal isteri sakit ingatan dan tidak dapat hadir di persidangan; (c) Hakim meminta suami membuat pernyataan secara tertulis yang isinya menyatakan kesediannya akan berlaku adil dan mampu menjamin kehidupan isteri-isteri dan anak-anaknya. (2) Upaya isteri untuk mempertahankan hak-haknya yang tidak dipenuhi oleh suaminya yang 
berpoligami adalah isteri dapat mengajukan tuntutan hak ke pengadilan agama jika para pihak beragama Islam, dan ke pengadilan negeri jika para pihak non muslim.

Jika perkawinan (poligami) dilakukan tanpa izin istri pertama dan pengadilan Agama, maka pernikahan tersebut tidak sah atau pernikahan tersebut tidak mempunyai kekuatan hukum. Dalam kasus perkawinan tanpa izin seorang istri Poligami) peneliti mewawancarai Ketua Pegadilan Agama Kelas 1B Kota Ternate dalam pernyataannya adalah sebagai berikut:

Apabila bila seoran suami tahu bahwa dia sudah dalam ikatan perkawinan namun tetap menikah dengan orang lain tanpa izin, maka suami tersebut akan dikenakan sanksi hukuman yang sangat tegas, sebagaimana dipertegas dalam Surat Edaran Mahkamah Agung No. 4 Tahun 2016 tentang Pemberlakuan Rumusan Hasil Rapat Pleno Kamar Mahkamah Agung 2016 Sebagai Pedoman Pelaksanaan Tugas Pengadilan yang menyatakan sebagai berikut: Bahwa perkawinan yang dilangsungkan oleh seorang suami dengan perempuan lain sedangkan suami tersebut tidak mendapatkan izin isteri untuk melangsungkan perkawinan lagi, maka Pasal 279 KUHPidana dapat diterapkan."

Berdasark hasil wawancar kepada ketua Pengadilan Agama Kelas 1B Kota Ternate, dapat disimpulkan bahwa terhadap suami yang menikah lagi tanpa izin dari isteri pertama (terdahulu) maka bisa dikenakan Pasal 279 Kitab Undang-Undang Hukum Pidana (KUHP), dengan ancaman pidana maksimal 5 sampai 7 tahun penjara.

\section{Penutup}

Pernikahan Tanpa Persetujuan salah satu Pihak dalam Perspektif Hukum Perdata dan Hukum Islam di Kota Ternate, dalam hukum pertada dapat dibatalkan demi hukum, karena tidak memenuhi sayarat-syarat yang ditentukan oleh undang-undang. Dan dalam tinjauan hukum Islam tidak ada perbedaan tidak ada perbedaan pelaku poligami dan orang yang menikahkan pelaku poligami mendapat hukuman yang sama antara pelaku langsung dan pelaku 
tidak langsung, sebab perbuatan masing-masing pembuat tersebut termasuk jarimah ta"zir dan hukumannya juga hukuman ta"zir. Sedangkan syara" tidak memisahkan antara jarimah ta"zir yang satu dan jarimah ta"zir lainnya. Selama hakim mempunyai kebebasan dalam menentukan besar kecilnya hukuman ta"zir, maka tidak ada perlunya membuat pemisahan antara hukuman perbuatan langsung dengan hukuman perbuatan tidak langsung dalam jarimah ta"zir. Penyelesaian Hukum Terhadap Kasus Pernikahan Tanpa Persetujuan salah satu pihak pada Polda Maluku Utara dan Pengadilan Agama Kota Ternate. Bahawa penyelesaian hukum di polda dengan pelanggara tersebut berdasakan hasil yang peneliti temukan, diberikan ancaman pidana maksimal 5 sampai 7 tahun penjara. jika seorangsuami yang kawin lagi tanpa izin pengadilan, maka terhadapnya harus diterapkan ketentuan pidana dalam Pasal 279 ayat (1) ke 1 KUHP, yaitu ancaman pidana selama lima tahun, dan penyelesaian di Pegadilan Agama Kelas 1B Kota Ternate, dapat melakukan pembatalan pernikahan dengan syarat permohomonan guagatan dari pihak korban. Dan diberikan Sanksi hukum orang yang menikahkan pelaku poligami tanpa izin Istri yang tegas.

Daftar Pustaka

Abidin, Slamet, and Aminuddin. Fiqih Munakahat II. Bandung: Pustaka Setia, 2009. Abubakar, Zainal Abidin. Kumpulan Peraturan Perundang-Undangan Dalam Lingkungan Peradilan Agama. Jakarta: Yayasan Al-Hikmah, 2011. Al-Zuhaili, Wahbah. Figh Islam Wa Adillatuhu. Bogor: Gema Insani Press, 2007. Ali, Mohammad Daud. Hukum Islam. Jakarta: PT. Raja Grafindo Persada, 2001. Amir, Syarifuddin. Hukum Perkawinan Di Indonesia. Jakarta: Prenada Media Group, 2009.

Chandrawila Supriadi, Wila. Hukum Perkawinan Di Indonesia Dan Belanda. Bandung: Mandar Maju, 2002.

Departemen Agama RI. Al-Qur'an Dan Terjemahan. Jakarta: Pustaka Amani, 2006.

Direktorat Pembinaan Badan Peradilan Agama, Direktorat Jenderal Pembinaan 
Kelembagaan Agama Islam. Kompilasi Hukum Islam, n.d.

Ghozali, Abdul Rahman. Fiqih Munakahat. Jakarta: Kencana, 2008.

- - - Fiqih Munakahat. Jakarta: Kencana Prenada Media Group, 2012.

Hanafi, Ahmad. Asas-Asas Hukum Pidan Islam. Jakarta: Bulan Bintang, 2005.

Hasan, Ayyub Syaikh. Fikih Keluarga. Jakarta: Pustaka Al-Kautsar, 2004.

HS., Salim. Pengantar Hukum Perdata Tertulis (BW). Yogyakarta: Sinar Grafika, n.d.

Khoirul, Abror. Hukum Perkawinan Dan Perceraian. Jakarta: Bumi Aksara, 2015.

Manan, Abdul. Aneka Masalah Hukum Perdata Islam Di Indonesia. Jakarta: Kencana, 2006.

Muhammad, Ahsin Sakho. Ensiklopedi Hukum Pidana Islam. Bogor: Kharisma Ilmu, 2005.

Mulia, Siti Musdah. Islam Menggugat Poligami. Jakarta: Gramedia Pustaka Utama, 2004.

Muslih, Ahmad Wardi. Pengantar Dan Asas Hukum Pidana Islam. Jakarta: Sinar Grafika, 2006.

Nuruddin, H. Amiur, and Azhari Taringan. Hukum Perdata Islam Di Indonesia. 3rd ed. Jakarta: Kencana, 2006.

Presiden Republik Indonesia. Intruksi Presiden Republik Indonesia Nomor 1 Tahun 1991 Tentang Kompilasi Hukum Islam, 1991.

Republik Indonesia. KITAB UNDANG-UNDANG HUKUM PERDATA (Burgerlijk Wetboek Voor Indonesie). Indonesia, n.d.

Republik Indonesia, Presiden. Undang-Undang Nomor 1 Tahun 1974 Tentang Perkawinan. Indonesia, 1974.

Rofiq, Ahmad. Hukum Perdata Islam Di Indonesia. Jakarta: PT. Raja Grafindo Persada, 2013.

Sabiq, Sayyid. Fikih Sunnah. 12th ed. Bandung: Darul Ma'arif, 1996.

Saebani, Beni Ahmad. Fikih Munakahat 1. Bandung: Pustaka Setia, 2009.

Soekanto, Soerjono, and Sri Mamudji. Penelitian Hukum Normatif (Suatu Tinjauan Singkat). Jakarta: Rajawali Pers, 2001.

Soemiyati. Hukum Perkawinan Islam Dalam Undang-Undang Perkawinan (UndangUndang Nomor 1 Tahun 1974 Tentang Perkawinan). 4th ed. Yogyakarta: Liberty, 
2003.

Ulfa, Muhdan. Tinjauan Yurudis Terhadap Perkawinan Tanpa Akad Nikah Menurut Undang-Undang Nomor 1 Tahun 1974 Dan Kaitannya Dengan Hukum Islam. Jakarta: Persada Media, 2008.

Zaber Wahid, Muhammad. Data Kasus Pernikahan (Poligami) Tanpa Persetujuan Salah Satu Pihak Di Kepolisian Daerah Maluku Utara 2013-2017. Ternate, 2017. 